\title{
Analisis Sensor Regangan dengan Teknik Pencacatan Berbasis Serat Optik Multimode Step-Index
}

\author{
Muhadha Shalatin dan Agus Rubiyanto \\ Departemen Fisika, Fakultas Ilmu Alam, Institut Teknologi Sepuluh Nopember (ITS) \\ e-mail: arubi@physics.its.ac.id
}

\begin{abstract}
Abstrak-Penelitian sensor regangan dengan variasi pencacatan pada serat optik multimode step index tipe FD-620-10 yang memiliki diameter serat $1 \mathrm{~mm}$ telah dilakukan. Cladding serat optik diberikan pencacatan dengan variasi pencacatan sebanyak 1 sampai 5 buah dengan lebar pencacatan $3 \mathrm{~mm}$ dan jarak antar pencacatan dibuat dengan ukuran yang sama yaitu sebesar $1 \mathrm{~cm}$. Untuk mengetahui besaran daya keluaran akibat regangan digunakan LED (Light Emitting Diode) panjang gelombang 660 nm sebagai sumber cahaya, microdisplacement, dan BF5R-D1-N sebagai detektor cahaya. Pengukuran sensor regangan berbasis serat optik menunjukkan bahwa sensitivitas dengan pencacatan lebih bagus dari fiber optik normal.
\end{abstract}

Kata Kunci-BF5R-D1-N, Sensor Regangan, Serat Optik, Teknik Pencacatan.

\section{PENDAHULUAN}

$\mathrm{P}$ ERKEMBANGAN serat optik yang pesat menyebabkan aplikasi serat optik saat ini tidak hanya dimanfaatkan sebagai media transmisi tetapi juga sebagai sensor. Sensor regangan menggunakan serat optik memiliki kelebihan dibandingkan dengan sensor lain karena serat optik itu sendiri unggul dalam ukuran yang kecil, tahan terhadap interferensi elektromagnetik dan radiasi cahaya tidak terpengaruh pada sifat bahan sehingga dapat diletakkan dengan bahan komposit secara non-obstrusive (tanpa desakan) [1].

Sensor serat optik sebagai sensor pergeseran dengan metode yang sederhana juga telah dilakukan yaitu terintegrasi akustikoptik interferometer heterodyne dikembangkan untuk sensor pergeseran [2]. Selain itu, aplikasi directional coupler serat optik sebagai sensor pergeseran [3] dan sensor berbasis serat optik struktur SMS (Singlemode Multimode Singlemode) dengan pencacatan 1,2,3 pada serat optik dengan memanfaatkan fasilitas pada OTDR dimana pengukuran beberapa titik pergeseran dapat dilakukan secara serempak [4].

Berbagai jenis sensor serat optik untuk mengukur regangan (Strain) dan pergeseran (Displacement) telah banyak dikembangkan. Regangan didefinisikan sebagai depormasi benda yang dapat dinormalkan kebentuk semula dalam satu dimensi atau perbandingan perubahan panjang dengan panjang mula-mula benda tersebut. Sedangkan pergeseran didefinisikan sebagai perubahan posisi suatu objek dengan mempertimbangkan besar dan arah dari posisi awal ke posisi akhir [5]. Pada penelitian ini akan dilakukan eksperimen sensor regangan dengan teknik pencacatan pada serat optik plastik mengunakan sumber cahaya LED dan detektor cahaya dari BF5R-D1-N sehingga tingkat sensitivitas lebih utamakan.

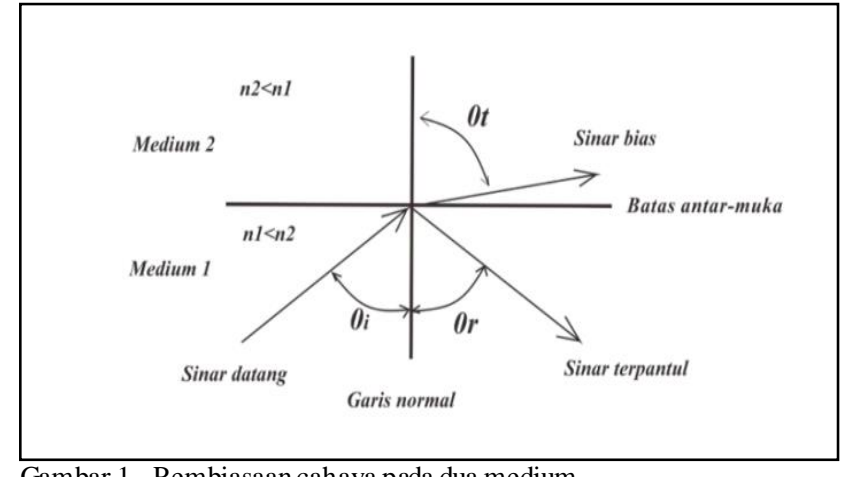

Gambar 1. Pembiasaan cahaya pada dua medium.

Serat optik merupakan helaian optik murni yang sangat tipis dan dapat memtransmisikan cahaya. Bagian-bagian sebuah serat optik tunggal terdiri dari inti (kaca tipis yang berada ditengah serat yang digunakan sebagai jalan cahaya), pembungkus (bagian optikal terluar yang mengelilingi inti yang berfungsi untuk memantulkan cahaya kembali ke inti), serta jaket penyangga (jaket plastik yang melindung serat dari temperatur dan kerusakan)[6].

Syarat yang harus dipenuhi oleh bagian cladding ini adalah indeks bias core $\left(\mathrm{n}_{\mathrm{cr}}\right)$ harus selalu lebih besar dari indeks bias cladding $\left(\mathrm{n}_{\mathrm{cl}}\right)$. Hal ini bertujuan agar terjadi pantulan dalam total pada cahaya didalam core sehingga tidak lolos menembus cladding. Dalam keadaan ideal tidak terdapat energi yang hilang di dalam core. Ada pun bagian pelengkap yang terdapat pada serat optik adalah jaket (coating), yakni bagian terluar yang berfungsi melindungi bagian core dan cladding dari kerusakan akibat pengaruh eksternal dari serat optik [7].

Jenis serat optik berdasarkan struktur indeks bias core yaitu step index dan graded index. Pada serat optik step index mempunyai satu indeks bias yang homogen baik ditengah core sampai batas core dan cladding. Sedangkan graded index memiliki indeks bias berubah pada core nya, indeks bias semakin besar saat mendekat ke tengah sumbu core dan menurun secara gradual pada batas core dengan cladding [8].

Perambatan cahaya didalam serat optik terkait dengan indeks bias dielektrik medium. Indeks bias medium didefinisikan sebagai rasio kecepatan cahaya didalam hampa terhadap kecepatan cahaya didalam medium. Kecepatan cahaya dalam medium rapat lebih kecil dibanndingkan dengan kecepatan cahaya dalam medium renggang. Bila sinar datang pada antar muka antara dua dielektrik yang indeks biasnya berbeda (misal kaca dan udara), maka terjadi pembiasaan seperti Gambar 1. 


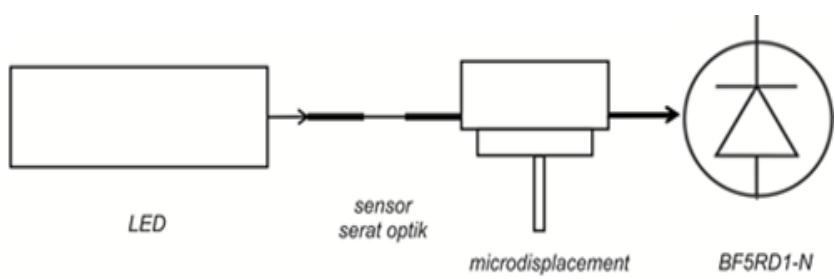

Gambar 2. Skema rangkaian alat.

Lintasan cahaya melalui dua medium berbeda dengan indeks bias medium berbeda dengan indeks bias medium satu $\left(\mathrm{n}_{1}\right)$ dan indeks bias medium dua $\left(\mathrm{n}_{2}\right)$ akan mengalami pembiasaan sebesar sudut tertentu yang dijelaskan berdasarkan persamaan Snellius :

$$
\frac{\sin \emptyset_{1}}{\sin \emptyset_{2}}=\frac{n_{1}}{n_{2}}
$$

Apabila perambatan cahaya bergerak dari medium rapat $\left(\mathrm{n}_{2}\right)$ dengan sudut datang terhadap normal bidang $\left(\emptyset_{2}\right)$ menuju medium kurang rapat $\left(\mathrm{n}_{1}\right)$ maka dibiaskan sebesar $\left(\emptyset_{1}\right)$. Karena $\mathrm{n}_{2}>\mathrm{n}_{1}$. Sudut bias $\left(\emptyset_{1}\right)$ akan lebih besar dari sudut datang $\left(\emptyset_{2}\right)$. Hingga suatu ketika memenuhi suatu kondisi sudut datang kritis $(\varnothing c)$ adalah sudut yang menghasilkan sudut bias $\left(\emptyset_{1}\right)$ bernilai $90^{\circ}$, Dapat dituliskan dalam persamaan :

$$
\emptyset c=\sin ^{-1} \frac{n_{1}}{n_{2}}
$$

Bila sudut datang lebih besar dari pada sudut kritis maka cahaya dipantulkan kembali ke medium dielektrik asal dengan sudut pantul yang nilainya sama dengan sudut datang cahaya. Fenomena ini dikenal dengan pantulan dalam total pada cahaya yang melalui dua medium berbeda [9].

Regangan adalah perbandingan antara perubahan panjang dengan panjang mula-mula sensor, sepertipersamaan,

$$
\varepsilon=\frac{\Delta L}{L_{o}}
$$

Dimana $\Delta L$ adalah perubahan panjang sensor serat optik polimer oleh pergeseran dan $L_{o}$ adalah panjang mula-mula sensor serat optik polimer [3].

\section{METODOLOGI PENELITIAN}

\section{A. Alat dan bahan}

Pada penelitian ini digunakan beberapa alat dan bahan. Adapun alat dan bahan yang digunakan dalam penelitian ini antara lain BF5RD1-N 2 buah, DIN Rail 2 buah, optical power meter, power supply 2 buah, serat optik tipe fd-620-10, alkohol 96\%, tissu, gunting, cutter, akrilik, penggaris $60 \mathrm{~cm}$, mikroskop stereo, microdisplacement, pelat tetap, pisau kecil, jangka sorong, selotip, dan fiber cutter.

\section{B. Cara Kerja}

Langkah - langkah yang dilakukan penelitian ini yaitu

1. Pengelupasan Coating pada Serat Optik
Pada tahap ini panjang serat optik yang digunakan sepanjang $30 \mathrm{~cm}$. Pemotongan serat optik menggunakan fiber cutter agar proses pemotongan rata dengan sempurna. Tahap selanjutnya dilakukan pengelupasan coating menggunakan alat kupas berupa akrilik untuk mempermudah pengupasan coating pada serat optik. Alat akrilik ini terdiri dari 2 bagian balok dengan menggunakan cutter proses pengelupasan dilakukan pada bagian tengah sepanjang $8 \mathrm{~cm}$ sehingga tersisa core dan cladding nya saja. Untuk mempermudah pengeluasan diberikan selotip di kedua ujung serat optik. Selain itu, untuk menjaga kebersihan serat optik yang telah dihilangkan coatingnya dilakukan sterilisasi menggunakan alkohol berkadar $96 \%$ dengan menggunakan tissu. Dalam penelitian ini disiapkan 5 buah serat optik yang sudah dipotong sepanjang $30 \mathrm{~cm}$.

2. Teknik Pencacatan

Pencacatan pada struktur serat optik polimer dibuat dengan cara menggoreskan permukaan serat yaitu cladding menggunakan pisau kecil dan lancip. Menggoreskan permukaan serat sebanyak 20 goresan pada tiap titik nya. Jarak satu titik pencacatan dengan pecacatan lain $1 \mathrm{~cm}$. Terdapat 5 variasi pencacatan yaitu 1 pencacatan, 2 pencacatan, 3 pencacatan, 4 pencacatan dan 5 pencacatan dengan lebar pencacatan yang sama sebesar 3 au. Selain itu sebuah serat optik yang masih terdapat coating dibuat pembanding kondisi seawal tanpa diberikan pencacatan.

3. Pengamatan Struktur Permukaan

Sebelum dilakukan perangkaian alat dilakukan pengamatan pada struktur permukaan serat optik. Hal ini dilakukan dengan tujuan untuk mengamati bentuk permukaan serat optik yang telah dilakukaan pencacatan. Pengujian ini dilakukan di Lab. Metal, Jurusan Teknik Material dan Metalurgi ITS. Dalam pengujian ini alat yang digunakan yaitu mikroskop stereo. Bagian serat optik yang telah dilakukan pencacatan diletakkan pada meja preparat pengamatan. Hasil pengamatan dapat diperbesar dengan skala mikro sehingga dapat dilihat pada komputer sepanjang daerah pencacatan.

4. Kalibrasi BF5RD1-N Menggunakan Optical Power Meter

Proses kalibrasi alat BF5RD1-N yaitu bertujuan untuk membandingkan daya keluaran dari BF5RD1-N dengan optical power meter sehingga hasil penelitian ini mendapatkan hasil daya keluaraan dalam satuan Watt. Optical power meter yang digunakan bertipe PM100D dengan range panjang gelombang $400 \mathrm{~nm}$ sampai dengan $1100 \mathrm{~nm}$.

5. Desain Dan Perangkaian Kerangka Alat

Pada tahap ini dilakukan pembuatan desain dan perangkaian alat. Peralatan yang menunjang untuk penelitan ini yaitu Power suppy digunakan sebagai sumber tegangan untuk mengaktifkan laser He-Ne. BF5RD1-N digunakan sebagai sumber cahaya yang berupa LED memiliki panjang gelombang $660 \mathrm{~nm}$. Serat optik polimer yang digunakan step index multimode tipe FD-620-10 dengan diameter core 0,88 $\mathrm{mm}$ dan diameter core + cladding $1 \mathrm{~mm}$. Statip adalah sebuah alat yang dipasang tetap berfungsi sebagai penahan serat optik dari tarikan microdisplacement. Microdisplacement digunakan sebagai mengatur pergeseran dalam ukuran mikro meter dan maksimum pergeserannya $1500 \mu \mathrm{m}$. Detektor cahaya yang digunakan yaitu BF5RD1-N. Optical power meter digunakan untuk kalibrasi hasil daya keluaran BF5RD1-N (Gambar 2). 


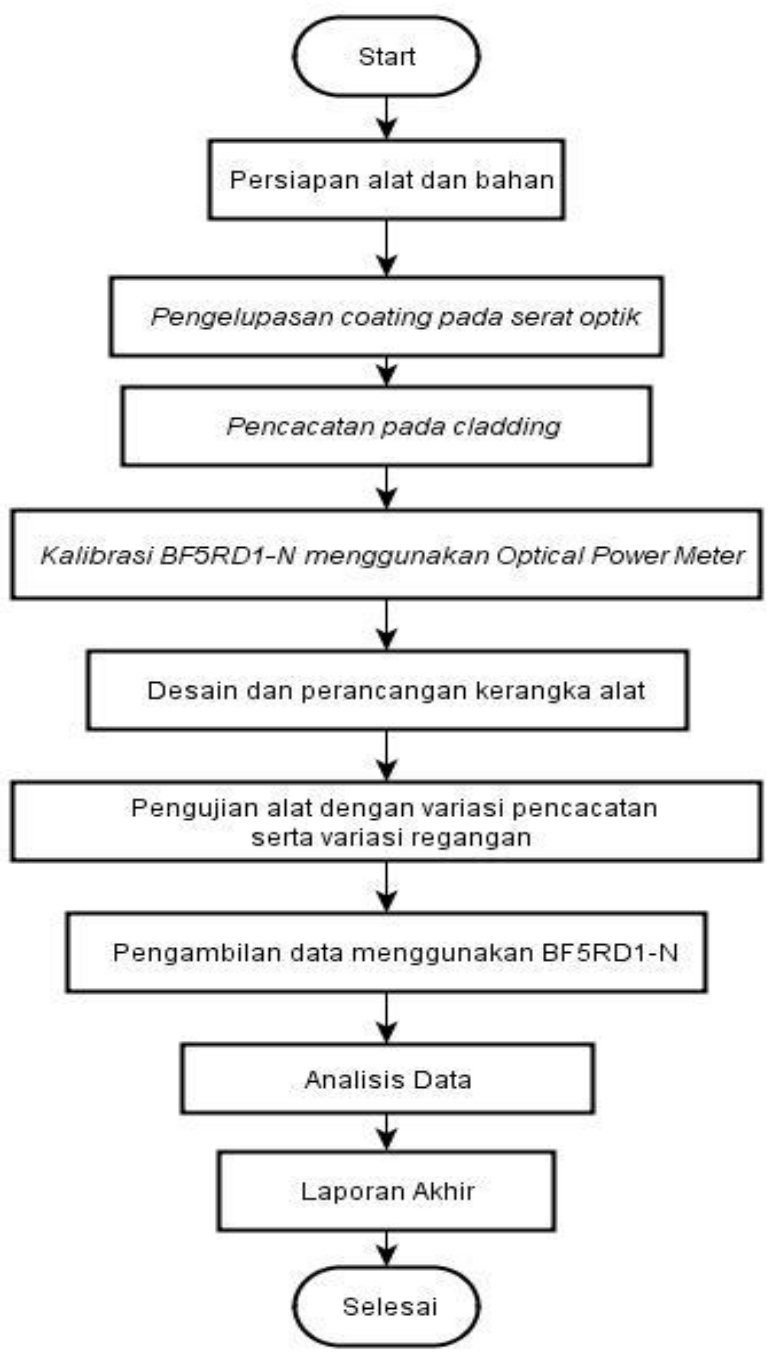

Gambar 3. Flowchart penelitian.

Sumber cahaya LED dari BF5RD1-N ditransmisikan melalui serat optik polimer yang diterima oleh detektor cahaya BF5RD1-N yang lain kemudian dilihat daya keluaran berupa intensitas cahaya. Kedua ujung serat optik polimer terhubung dengan LED dan detektor cahaya, sedangkan bagian tengah serat optik (serat optik yang telah dilakukan pencacatan) yang digunakan sebagai sensor terpasang antara plat tetap dan microdisplacement. Proses terjadinya regangan apabila diterapkan variasi regangan pada microdisplacement. Selanjutnya akan diukur daya keluaran yang diperoleh dari BF5RD1-N yang berfungsi sebagai receive.

6. Pengujian Alat Dengan Variasi Pecacatan Serta Variasi Regangan

Dalam penelitian ini digunakan variasi pencacatan dan variasi regangan, hal ini bertujuan untuk mengetahui pengaruh variasi terhadap rugi daya tersebut. Pada penelitian ini digunakan variasi pencacatan sebanyak 1 sampai 5 pencacatan dengan lebar pencacatan $3 \mathrm{~mm}$ dan jarak antar pencacatan dibuat dengan ukuran yang sama yaitu sebesar $1 \mathrm{~cm}$. Pada penelitian ini pengukuran tingkat sensitivitas dari sensor regangan dilakukan dengan beberapa variasi tegangan. Perubahan regangan setiap $1 \mu \mathrm{m}$ mulai dari $0 \mu \mathrm{m}$ hingga 13
Tabel 1.

Data intensitas keluaran menggunakan BF5RD1-N

\begin{tabular}{ccc}
\hline \hline No & Tegangan (Volt) & Output $(\mathrm{au})$ \\
\hline 1 & 8 & 1997 \\
2 & 8,5 & 2253 \\
3 & 9 & 2325 \\
4 & 9,5 & 2432 \\
5 & 10 & 2465 \\
\hline \hline
\end{tabular}

Tabel 2.

Data daya keluaran menggunakan optical power meter

\begin{tabular}{ccc}
\hline \hline No & Tegangan (Volt) & Output $(\mathrm{mW})$ \\
\hline 1 & 8 & 0,276 \\
2 & 8,5 & 0,31 \\
3 & 9 & 0,345 \\
4 & 9,5 & 0,372 \\
5 & 10 & 0,379 \\
\hline \hline
\end{tabular}

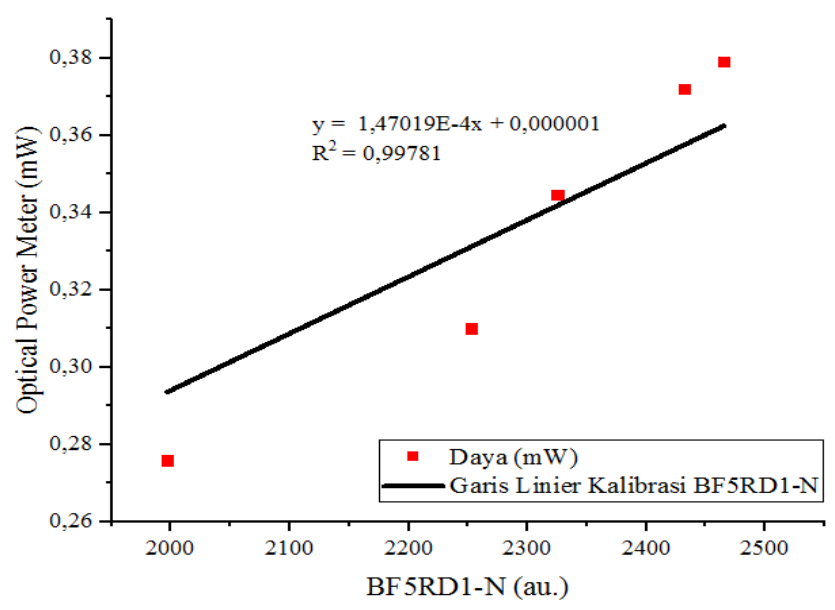

Gambar 4. Kalibrasi BF5RD1-N menggunakan optical power meter.

$\mu \mathrm{m}$. Flowchart dari percobaan ini dapat dilihat pada Gambar $3)$.

\section{HASIL DAN PEMBAHASAN}

Dalam penelitian rancangan sensor regangan serat optik dengan teknik pencacatan telah dilakukan. Dari hasil pengukuran menggunakan BF5R-D1-N diperoleh grafik hubungan daya keluaran dan regangan serta data dalam format excel terdiri dari regangan dan intensitas cahaya yang kemudian konversikan menjadi regangan dan daya keluaran. Eksperimen dalam penelitian ini menggunakan metode sederhana, menggunakan sumber cahaya LED infra merah yang bersumber dari BF5R-D1-N, serat optik, dan microdisplasment.

\section{A. Analisa Data}

Dalam penelitian ini dilakukan variasi-variasi pengambilan data pada serat optik untuk mengetahui tingkat sensitivitas serat optik setelah dilakukan pencacatan. Variasi yang dilakukan antara lain variasi banyaknya pencacatan dan variasi regangan. 


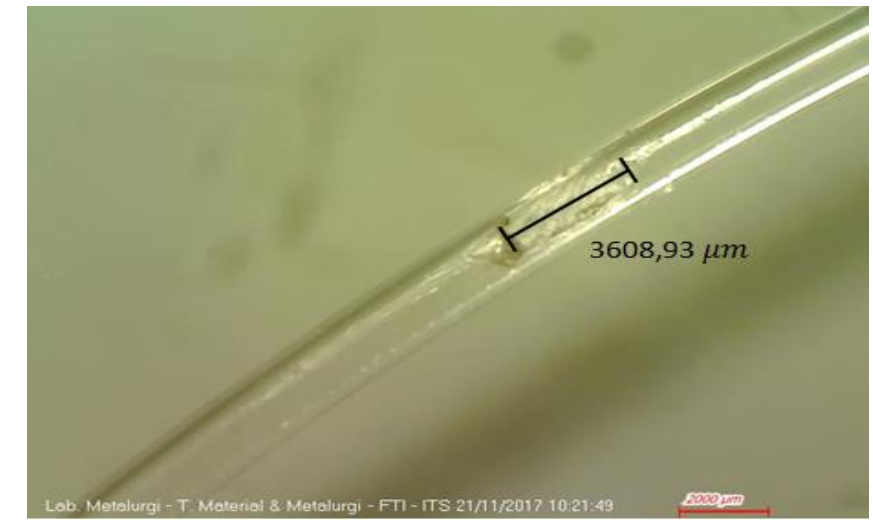

Gambar 5. Hasil pengamatan mikroskop stereo pada serat optik yang dilakukan satu pencacatan.

Sebelum dilakukan rancangan sensor regangan serat optik dengan teknik pencacatan terlebih dahulu dilakukan uji kondisi awal sensor serat optik. Sensor serat optik yang digunakan yaitu serat optik plastik multimode step index tipe FD-620-10 buatan Autonics dengan menggunakan jangka sorong dilakukan pengukuran secara langsung pada serat optik dan diperoleh diameter core sebesar $0,8 \mathrm{~mm}$ seperti pada dan cladding 0,2 $\mathrm{mm}$, sehingga diameter gabungan core dan cladding $1 \mathrm{~mm}$. Serat optik tipe FD-620-10 ini memiliki indeks bias core 1,492 dan indeks bias cladding 1,417 dengan nilai numerical aperture (NA) sebesar 0,5 dengan sudut keluaran $60^{\circ}$ yang memiliki bentuk seperti kerucut. Bahan core dan cladding serat optik FD-620-10 terbuat dari resin sintetik poly akrilik. Hasil kalibrasi BF5R-D1-N menggunakan optical power meter di tunjukkan pada Tabel 1 dan 2.

Dari hasil pengukuran tersebut, dibuat grafik kalibrasi pada gambar 4 terdapat persamaan yang berada pada garis linier y $=0,147019 \cdot 10^{-4} \mathrm{x}+0,000001$ yang mempunyai nilai koefisien determinasi $\mathrm{R}^{2}=0,99781$. Maka persamaan $\mathrm{y}$ mengartikan bahwa y fungsi x. Artinya bila y adalah tegangan optical power meter fungsi $\mathrm{x}$ adalah intensitas cahaya BF5RD1-N, maka nilai tegangan optical power meter tergantung pada intensitas cahaya BF5RD1-N. Persamaan regresi diatas menunjukan nilai $\quad 0,147019.10^{-4} \mathrm{x}$. Nilai $\quad 0,147019.10^{-4} \mathrm{x}$ menunjukan slope yang menunjukan arah regeresi linier. Bisa diartikan menunjukan angka peningkatan ataupun penurunan variabel. Bila (+) maka naik dan bila (-) maka terjadi penurunan. Karena angka koefisien regresinya (+) maka mengalami penaikan variabel.

Sedangkan nilai 0,000001 disebut intercept. Dalam hal ini intercept mengartikan bahwa pada nilai awal perhitungan pada BF5RD1-N, maka nilai optical power meter sebesar 0,000001 Watt. Sehingga 0,000001 Watt bisa dijadikan nilai terkecil dari optical power meter. Pada gambar 4. diperoleh koefisien determinasi $\mathrm{R}^{2}=0,9584$. Terlebih dahulu mencari nilai $\mathrm{R}$, nilai $\mathrm{R}$ ini merupakan koefisien korelasi. Dengan kata lain keeratan korelasi antara optical power meter dengan BF5RD1-N yaitu sebesar 0,9989. Nilai 0,9989 diperoleh dari nilai 0,9585 diakarkan didapatkan hasil 0,9989. Berdasarkan tabel nilai koefisien korelasi, maka termasuk kategori sangat kuat karena berada pada range nilai koefisien korelasi 0,801,00. Jadi, korelasi antara optical power meter terhadap BF5RD1-N sangat kuat. Perubahan nilai optical power meter

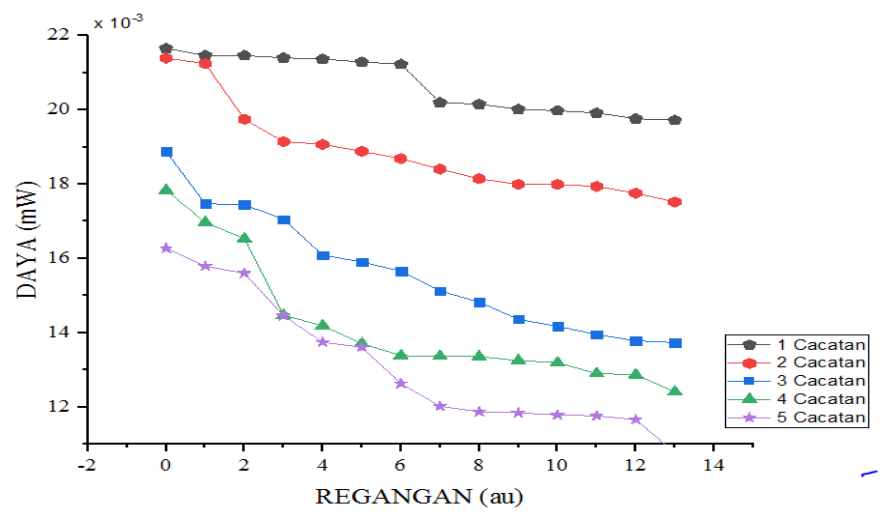

Gambar 6. Hubungan regangan dengan daya pada sensor regangan.

terhadap BF5RD1-N sebanyak 95,85 \% sedangkan sisanya merupakan faktor lain diluar variabel bebasnya (Gambar 4).

Proses pengamatan pencacatan dilakukan di Lab. Metalurgi, jurusan teknik material dan metalurgi, Institut Teknologi Sepuluh Nopember. Dari pengamatan menggunakan mikroskop stereo diperoleh pengamatan pencacatan pada serat optik di tunjukkan pada Gambar 5. Berdasarkan pengamatan dari Gambar 5 diperoleh lebar pencacatan pada serat optik satu pencacatan sebesar 3,608 au. Hasil pengukuran sensor regangan serat optik ditunjukkan pada Gambar 6 .

Nilai regangan adalah perbandingan antara perubahan panjang dengan panjang mula-mula sensor. Jadi nilai yang terdapat pada regangan diatas adalah perubahan panjang. Misal perubahan panjang yaitu $1 \mu \mathrm{m}$, maka nilai regangan,

$$
\varepsilon=\frac{1}{L_{o}}
$$

Dari hasil pengukuran daya keluaran yang telah disajikan pada Gambar diatas dapat dilakukan perhitungan nilai sensitivitas yaitu daya keluaran maksimum dikurangi daya minimum dibagi regangan maksimum dikurangi regangan minimum. Sedangkan resolusi pengukuran merupakan nilai terkecil yang mampu dideteksi oleh suatu alat ukur.

Sensitivitas pada penelitian ini dapat dihitung dengan menggunakan persamaan,

$$
\mathrm{S}=\frac{P_{\max }-P_{\min }}{\varepsilon_{\max }-\varepsilon_{\min }}
$$

dimana $\varepsilon_{\max }$ dan $\varepsilon_{\min }$ adalah regangan maksimum dan regangan minimum. Resolusi dapat dihitung dengan menggunakan persamaan,

$$
\mathrm{R}=\frac{N}{S}
$$

dimana $\mathrm{N}$ adalah skala terkecilnya optical power meter yaitu $0,001 \mu \mathrm{W}$ dan $\mathrm{S}$ adalah nilai sensitivitas. (Tabel 3)

\section{B. Pembahasan}

Sensor berbasis serat optik dalam penelitian ini termasuk sensor intrinsik. Sensor intrinsik memiliki stabilitas sinyal yang lebih tinggi karena daya keluaran sesuai dengan variasi parameter yang diukur. Dalam rancangan sensor serat optik 
Tabel 3.

Hasil sensitivit as dan resolusi sensor regangan

\begin{tabular}{ccc}
\hline \hline Variasi Pencacatan & Sensitivitas (Watt/au) & Resolusi (au) \\
\hline 1 & 0,000148602 & 0,006729 \\
2 & 0,000297883 & 0,003357 \\
3 & 0,000395594 & 0,002528 \\
4 & 0,000417308 & 0,002396 \\
5 & 0,000422962 & 0,002364 \\
\hline \hline
\end{tabular}

menggunakan LED merah dari BF5R-D1-N sebagai sumber cahaya. LED memiliki daya keluaran yang lebih kecil, kecepatan swiching yang lebih lambat dan lebar spektrum yang lebih besar. LED digunakan secara luas untuk sistemsistem rentang pendek dan menengah yang menggunakan serat optik kaca dan plastik seperti sensor karena dayanya yang lebih rendah sehingga membuat LED lebih aman digunakan. LED merah dari BF5R-D1-N ini memiliki panjang gelombang $660 \mathrm{~nm}$ dengan bahan yang digunakan yaitu semikonduktor dengan sambungan p-n yang memancarkan cahaya ketika diberi tegangan bias maju. BF5R-D1-N juga digunakan sebagai detektor cahaya. Adapun prinsip semikonduktor yang terdapat pada BF5R-D1-N adalah NPN (Negatif-PositifNegatif). Lapisan semikonduktor tipe $\mathrm{P}$ yang diapit 2 semikonduktor tipe N. Ketiga bagian transistor ini disebut emitor, basis, dan kolektor. Semikonduktor tipe-N yang lebih kecil akan menjadi daerah emitor. Pada semikonduktor tipe-N menjadi daerah emitor ini disisipkan lebih banyak logam pengotor dibandingkan dengan semikonduktor tipe $\mathrm{N}$ menjadi daerah kolektor. Sehingga pada daerah emitor lebih banyak terdapat elektron bebas dibandingkan dengan daerah kolektor. Sedangkan semikonduktor tipe-P yang menjadi daerah basis dibuat tipis dan banyak mengandung muatan positif (lubang). Arus yang mengalir antara basis dan emior untuk menglrkan arus lebih besardari kolektor ke emitor.

Sebelum dilakukan perancangan sensor regangan terlebih dahulu dilakukan kalibrasi pada BF5R-D1-N menggunakan Optical Power Meter. Kalibrasi BF5R-D1-N dilakukan di Lab. Rekayasa Fotonika Jurusan Teknik Fisika ITS. Proses kalibrasi BF5R-D1-N yaitu membandingkan hasil keluaran menggunakan detektor BF5R-D1-N dengan hasil keluaran detektor Optical Power Meter. Sumber cahaya yang digunakan dalam kalibrasi yaitu LED merah dari BF5R-D1-N. Sumber cahaya dan detektor cahaya (BF5R-D1-N dan Optical Power Meter) dihubungkan dengan serat optik berukuran 10 $\mathrm{cm}$. Kemudian diamati hasil daya keluarannya pada masingmasing detektor cahaya. Proses pengambilan data dilakukan pengulangan banyak 10 kali pengulangan. Hal ini dilakukan bertujuan mengetahui tingkat presisi dan akurasi pada pengambilan data.

Panjang serat optik yang digunakan $30 \mathrm{~cm}$. Sedangkan panjang sensor serat optik $8 \mathrm{~cm}$ berada pada tengah serat optik. Setelah dilakukan pencacatan pada cladding dengan lebar pencacatan $3 \mathrm{~mm}$. Menentukan lebar pencacatan dilakukan pengamatan menggunakan mikroskop stereo. Mikroskop stereo dapat mengamati sampel dengan perbesaran 7 hingga 30 kali sehingga dapat mengamati walaupun bendanya sangat kecil. Ruang ketajaman lensa mikroskop stereo jauh lebih tinggi dibandingkan dengan mikroskop cahaya sehingga sampel yang diamat berbentuk 3D. Sumber cahaya berasal dari atas sehingga objek yang tebal dapat diamati. Perbesaran lensa okuler biasanya 10 kali sedangkan lensa objektif menggunakan sistem zoom dengan perbesaran total maksimal 30 kali.

Prinsip dasar sensor berbaris serat optik yaitu terjadinya perubahan amplitudo atau intensitas cahaya yang ditransmisikan melalui serat optik. Intensitas cahaya yaitu energi cahaya yang dipindahkan dalam tiap satuan waktu dan tiap satuan luas. Cahaya LED yang merambat dalam serat optik menyebabkan terjadinya perbedaan intensitas setelah keluar dari serat optik. Sedangkan prinsip dasar sensor regangan berbasis serat optik adalah terjadinya perubahan panjang pada serat optik polimer akibat tarikan oleh microdisplacement yang menyebabkan penurunan daya keluaran pada sensor yang terukur pada BF5R-D1-N sebagai detektor cahaya. Bila regangan yang diterapkan pada sensor semakin besar, maka daya keluaran pada sensor regangan semakin berkurang.

Proses pemanduan gelombang cahaya bisa terjadi karena dua syarat pemanduan gelombang yaitu pemanduan dalam total dan indek bias $\mathrm{n}_{2}>\mathrm{n}_{1}$ sehingga suatu ketika memenuhi suatu kondisi sudut datang kritis $\left(\emptyset_{c}\right)$ adalah sudut yang menghasilkan sudut bias $\left(\emptyset_{1}\right)$ bernilai $90^{\circ}$. Berdasarkan tabel 4.5 setelah dilakukan pengukuran sensor regangan berbasis serat optik diperoleh hasil sensitivitas tanpa pencacatan sebesar 0,0004 $\mathrm{mW} / \mathrm{au}$ dengan resolusi $0,002498 \mathrm{au}$. Sedangkan serat optik dengan satu pencacatan diperoleh $0,000148 \mathrm{~mW} / \mathrm{au}$ dan resolusi 0,006729 au. Pada dua pencacatan diperoleh sensitivitas $0,000297 \mathrm{~mW} / \mathrm{au}$ dengan resolusi 0,003357 au. Pada tiga pencacatan diperoleh sensitivitas 0,000395594 $\mathrm{mW} / \mathrm{au}$ dengan resolusi $0,002528 \mathrm{au}$. Hasil sensitivitas dan resolusi sensor regangan pada empat pencacatan diperoleh 0,000417 $\mathrm{mW} / \mathrm{au}$ dan 0,002396 au. Dan hasil sensitivitas dan resolusi sensor regangan pada lima pencacatan diperoleh $0,00042 \mathrm{~mW} / \mathrm{au}$ dan 0,002364 au. Metode ini mampu meningkatkan sensitivitas dan resolusi sensor yang sebanding dengan banyak jumlah pencacatan. Semakin banyak jumlah pencacatan, maka semakin tinggi pula sensitivitas dan resolusi sensor yang dihasilkan semakin kecil.

\section{KESIMPULAN}

Pada penelitian ini telah dilakukan sensor regangan dengan teknik pencacatan serat optik multimode step index menggunakan BF5RD1-N. Metode ini mampu meningkatkan sensitivitas dan resolusi sensor yang sebanding dengan banyak jumlah pencacatan. Semakin banyak jumlah pencacatan, maka semakin tinggi pula sensitivitas dan resolusi sensor yang dihasilkan semakin kecil.

\section{DAFTAR PUSTAKA}

[1] L. Jingsong and A. Asundi, "Sensor and Actuaturs," 2003.

[2] A. Rubiyanto, "Integrated Acousto-Optical Heterodyne Interferometer for Displacement Measurement," J. Ilm. Sains dan Teknol., vol. 6, no. 1, pp. 1-4, 2007.

[3] P. Hadi and A. . Yunus, "Aplikasi Directional Coupler Serat Optik sebagai Sensor Pergeseran,” J. Fis. Dan Apl., vol. 4, no. 2, 2008.

[4] Arifin, "Pengembangan Sensor Regangan dan Pergeseran Berba sis Serat Optik,"Institut Teknologi Sepuluh Nopember Surabaya, 2015. 
[5] J. D'hooge et al., "Regional Strain and Strain Rate Measurement by Cardiac Ultrasound : Principles, Implementation and Limiation," Eur.J.Echocardiography, vol. 1, no.3, pp. 154-170, 2000

[6] A. R. Nugraha, Serat Optik, 1st ed. Yogyakarta, 2006.

[7] Abramczry, "Fundamental of Optical Fiber Transmission," Berlin,
2008.

[8] J. Power, An Introduction To Fiber Optic Systems, 2nd ed. New York: Mc Graw Hill, 1997.

[9] Widodo, Optoelektronika. Yogyakarta: Andi Offset, 1995. 